\title{
Hydrogen sulfide inhibits ethylene-induced petiole abscission in tomato (Solanum lycopersicum L.)
}

\author{
Danmei Liu ${ }^{1,2}$, Jianing $\mathrm{Li}^{1,2}$, Zhuowen $\mathrm{Li}^{1,2}$ and Yanxi Pei ${ }^{1,2}$
}

\begin{abstract}
Abscission is a dynamic physiological process that is ubiquitous in plants and can also be an essential agronomic trait in crops, thus attracting attention from plant growers and breeders. In general, the process of plant organ abscission can be divided into four steps, among which the step to obtain the competence to respond to abscission signals (step 2) is the most complex; however, the molecular mechanism underlying this process remains unclear. In this study, we found that hydrogen sulfide $\left(\mathrm{H}_{2} \mathrm{~S}\right)$ inhibited the abscission of the tomato petiole in a dose-dependent manner, and the abscission of the petiole was accelerated when an $\mathrm{H}_{2} \mathrm{~S}$ scavenger was applied. Further enzymatic activity and gene expression analyses showed that $\mathrm{H}_{2} \mathrm{~S}$ suppressed the activity of enzymes capable of modifying the cell wall by inhibiting the usual upregulation of the transcription of the corresponding genes during the abscission process but not by affecting the activities of these enzymes by direct posttranslational modification. $\mathrm{H}_{2} \mathrm{~S}$ treatment upregulated the expression levels of SIIAA3 and SIIAA4 but downregulated the transcription of ILR-L3 and ILR-L4 in the earlier stages of the abscission process, indicating that $\mathrm{H}_{2} \mathrm{~S}$ probably functioned in the second step of the abscission process by preventing the abscission zone cells from obtaining the competence to respond to abscission signals by modulating the content of the bioactive-free auxin in these cells. Moreover, similar $\mathrm{H}_{2} \mathrm{~S}$ inhibitory effects were also demonstrated in the process of floral organ abscission and anther dehiscence in other plant species, suggesting a ubiquitous role for $\mathrm{H}_{2} \mathrm{~S}$ in cell separation processes.
\end{abstract}

\section{Introduction}

Abscission is a critical process at different stages during the life span of a plant and ensures unwanted organs are shed from the main body of the plant ${ }^{1}$. It is also an important agronomic trait with major implications in terms of yield, quality, and postharvest storage in some crops $^{2,3}$. Abscission always occurs in a morphologically distinct area called the abscission zone (AZ). AZs are usually located at predetermined positions at the base of most plant organs, encompassing several layers of small, densely arranged cytoplasmic cells ${ }^{4}$. The formation of an AZ is the first step of the abscission process. Thereafter, through the perception of environmental and developmental signals, AZ cells attain the competence to respond to abscission signals (step 2) before the activation and

\footnotetext{
Correspondence: Yanxi Pei (peiyanxi@sxu.edu.cn)

${ }^{1}$ College of Life Science, Shanxi University, Taiyuan 030006, China

${ }^{2}$ Shanxi Key Laboratory for Research and Development of Regional Plants,

Taiyuan 030006, China
}

execution of abscission (step 3$)^{1}$. Finally, a protective layer is formed distal to the separation layers to protect the organs remaining on the plant from pathogen infection and water loss (step 4$)^{4-6}$.

As an essential physiological process that has been studied for many decades, many classical phytohormones have been shown to exert an influence over abscission, with ethylene and auxin reported to play central roles in the abscission process. Ethylene is regarded as an accelerator, whereas auxins decelerate abscission ${ }^{2,5,7}$. Evidence has shown that organ abscission is delayed in ethyleneinsensitive mutants of many plant species ${ }^{1,8,9}$, while auxins have been shown to inhibit abscission by rendering $\mathrm{AZ}$ cells insensitive to ethylene ${ }^{10,11}$. Modern agriculture manipulates the process of abscission to the growers' advantage by applying vinylogous, ethylene inhibitors or synthetic auxins to thin excess flower numbers early in the season and hence avoid overcropping or to prevent preharvest fruit drop later in the season in orchards ${ }^{1}$. 
Abscission is a process in which the cell adhesion within AZs is deliberately dissolved. The cell wall surface shared by adjacent cells is the main medium that maintains the adhesion between cells ${ }^{12,13}$, and nearly $90 \%$ of the cell wall mass consists of polysaccharides (mainly pectin, cellulose, hemicellulose, etc.). During the process of abscission, it has been reported that the expression and activity of cell-wall-modifying enzymes, which hydrolyze the cell wall and the middle lamella, increase markedly ${ }^{12,14}$. Among these enzymes, cellulases (Cels, endo-1,4-beta-glucanases), polygalacturonases (PGs), and expansins are essential members, and their functions have been investigated in cell separation processes ${ }^{14-16}$. It has been shown that silencing tomato PGs (TAPGs) greatly delayed abscission, even in the presence of ethylene, a major abscission accelerator ${ }^{14}$. Furthermore, the antisense suppression of tomato endo-1,4-beta-glucanase mRNA also increased the break strength of $\mathrm{AZs}^{17}$, indicating the principal roles of Cels and PGs in the process of cell wall degradation during abscission.

Hydrogen sulfide $\left(\mathrm{H}_{2} \mathrm{~S}\right)$ is a newly discovered gasotransmitter ${ }^{18}$. Recently, increasing evidence has demonstrated that $\mathrm{H}_{2} \mathrm{~S}$ possesses multiple physiological functions during the development of both animals and plants ${ }^{19,20}$. In tomato, limited studies have shown that $\mathrm{H}_{2} \mathrm{~S}$ is involved in the auxin- or methane-induced lateral root formation ${ }^{21,22}$, the modulation of fruit ripening via increasing antioxidant activity ${ }^{23}$, and the alleviation of stress caused by salt or excess nitrate through altering the redox status of the stressed plants ${ }^{24,25}$.

In this study, we explored the function of $\mathrm{H}_{2} \mathrm{~S}$ during the processes of plant organ abscission, especially with respect to petiole abscission in tomato, and investigated the mechanism underlying the inhibitory effects of $\mathrm{H}_{2} \mathrm{~S}$ on abscission. Our findings extended the understanding of the physiological roles of $\mathrm{H}_{2} \mathrm{~S}$ and provided further insights into the regulatory networks underlying the abscission process in plants.

\section{Materials and methods}

\section{Plant materials and growth conditions}

Seeds of the tomato cv. MicroTom were kindly provided by Dr. Yongfu Fu from the Institute of Crop Sciences, Chinese Academy of Agricultural Sciences, Beijing, China. All tomato plants were cultivated in a growth chamber under $24^{\circ} \mathrm{C} / 16$-h day and $18{ }^{\circ} \mathrm{C} / 8$-h night conditions.

\section{Petiole abscission assay}

Explants, including a $1.0-\mathrm{cm}$ length stem connected to an adjacent $1.0-\mathrm{cm}$ length petiole, were prepared from the nodal region of tomato plants with five to seven leaves prior to the reproductive stage. The explants were then inserted into $0.8 \%$ agar in a $400-\mathrm{ml}$ growth jar (five explants per jar, five replicates) and placed in the same growth chamber with the tomato plants. The explants were then divided into three groups: the ethylene treatment group, which was fumigated with ethylene (supplied by $40 \mu \mathrm{l}$ of $1 \mathrm{M}$ ethephon solution), the $\mathrm{H}_{2} \mathrm{~S}$-ethylene treatment group, which was treated with both ethylene and $\mathrm{H}_{2} \mathrm{~S}$ (supplied by $16 \mu \mathrm{l}$ of $1 \mathrm{M}$ sodium hydrosulfide $(\mathrm{NaHS})$ ), and the hypotaurine (HT)-ethylene treatment group, which was treated with both ethylene and the $\mathrm{H}_{2} \mathrm{~S}$ scavenger $\mathrm{HT}(1 \mathrm{mM})$. For both ethylene and $\mathrm{H}_{2} \mathrm{~S}$ treatment, their donors were not applied to the explants directly. The donor solutions were placed in sterile caps of centrifuge tubes, which were placed in the same growth jar with the explants, and the ethylene or $\mathrm{H}_{2} \mathrm{~S}$ generated by the donor solutions was used to fumigate the explants. To accelerate the release rate of ethylene from ethephon, ethephon was diluted with a sodium hydroxide $(\mathrm{NaOH})$ solution. The HT solution was applied directly, and explants in the other treatment groups were treated with double distilled water as a control. The petiole abscission of these three groups was recorded every $4 \mathrm{~h}$ and photographed at the time points $0,12,24,36$, and $48 \mathrm{~h}$ after initiation of the treatment. The abscission rates of the tomato petioles were also analyzed at different concentrations of $\mathrm{H}_{2} \mathrm{~S}$ (provided by $0,4,8,12,16,20$, or $40 \mu \mathrm{l}$ of $1 \mathrm{M} \mathrm{NaHS}$ solution) after treatment for $48 \mathrm{~h}$. An abscission event was defined as spontaneous petiole detachment or detachment in response to a gentle vibration applied to the distal part of the petiole ${ }^{26}$.

\section{Triple response assay}

The tomato seeds were surface-sterilized with 95\% ethanol for $30 \mathrm{~s}$ and $20 \%$ bleach for $20 \mathrm{~min}$, rinsed with distilled water 3-5 times, and placed in $12-\mathrm{cm}$ petri dishes with two layers of wet filter papers to germinate. When the roots of the seedlings began to emerge, the seedlings were divided into four treatment groups (ethylene, $\mathrm{H}_{2} \mathrm{~S}$, ethylene plus $\mathrm{H}_{2} \mathrm{~S}$, and the nontreatment control group). Ethylene and $\mathrm{H}_{2} \mathrm{~S}$ were applied as described above in the form of fumigation with ethephon ( $40 \mu \mathrm{l}$ of $1 \mathrm{M}$ solution) and NaHS $(16 \mu \mathrm{l}$ of $1 \mathrm{M}$ solution) as their donors, respectively. The phenotype of these seedlings was observed and photographed after growth in the dark for 4 days, and the hypocotyl lengths of these seedlings under different treatments were measured.

\section{$\mathrm{H}_{2} \mathrm{~S}$ content assay}

For the $\mathrm{H}_{2} \mathrm{~S}$ content assay, the AZ tissues prepared as mentioned above from the explants treated with different concentrations of $\mathrm{H}_{2} \mathrm{~S}$ for $24 \mathrm{~h}$ were used to analyze the $\mathrm{H}_{2} \mathrm{~S}$ content as described previously ${ }^{27}$. The petiole $\mathrm{AZ}$ tissues were first ground into homogenate with $1 \mathrm{ml}$ of phosphate buffer solution $(\mathrm{pH} 7.0,50 \mathrm{mM})$ containing $0.1 \mathrm{M}$ EDTA and $0.2 \mathrm{M}$ ascorbic acid. Then the homogenate was mixed with $1 \mathrm{ml}$ of $1 \mathrm{M} \mathrm{HCl}$ and placed in a 
closed vial to release $\mathrm{H}_{2} \mathrm{~S}$. The released $\mathrm{H}_{2} \mathrm{~S}$ was absorbed by a $1 \%(\mathrm{w} / \mathrm{v}) \mathrm{Zn}(\mathrm{AC})_{2}(0.5 \mathrm{ml})$ trap, which was also located in the vial. After incubation for $30 \mathrm{~min}, 100 \mu \mathrm{l}$ of

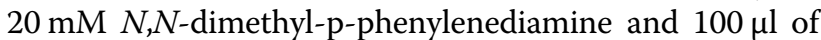
$30 \mathrm{mM} \mathrm{FeCl}_{3}$ were added to the $\mathrm{Zn}(\mathrm{AC})_{2}$ solution. After incubation in the dark for $15 \mathrm{~min}$, the absorbance was measured at $670 \mathrm{~nm}$ to determine the level of $\mathrm{H}_{2} \mathrm{~S}$ produced.

\section{Total RNA extraction and quantitative PCR (qPCR)}

Total RNA was extracted using RNAiso Plus (TaKaRa, Shiga, Japan) according to the manufacturer's instructions and then reverse transcribed into cDNA using an All-InOne RT MasterMix (abm, Nanjing, China), in which a finely balanced ratio of oligo $(\mathrm{dT}) \mathrm{s}$ and random primers was provided. A 7500 Fast Real-Time PCR system (Applied Biosystems, Foster City, USA) was used to perform the real-time qPCR, and a SAND family gene (Solyc03g115810) was used as an endogenous control ${ }^{28}$. The relative expression levels of genes were determined using the $2^{-\Delta \Delta C t}$ method $^{29}$. Each analysis was conducted with three biological and three technical replicates, and the primer sequences are listed in Table S1.

\section{PG activity assay}

The petiole explants were prepared and treated with ethylene or ethylene plus $\mathrm{H}_{2} \mathrm{~S}$ as described above. The treated $\mathrm{AZ}$ tissues were then cut off and placed in a precooled mortar with $1 \mathrm{ml}$ of extraction buffer $(50 \mathrm{mM}$ acetate buffer, $\mathrm{pH} 4.4$ ) and ground into a homogenate. After incubation for $3 \mathrm{~h}$ at $4{ }^{\circ} \mathrm{C}$, the homogenate was centrifuged ( $3000 \mathrm{rpm}$ for $20 \mathrm{~min}$ ), and the supernatant ("enzyme extract") was collected for the following analysis. Before the initiation of the reaction, an aliquot $(250 \mu \mathrm{l})$ of enzyme extract was preheated at $37^{\circ} \mathrm{C}$ for $3 \mathrm{~min}$, and then $500 \mu \mathrm{l} 1 \%$ polygalacturonic acid solution (in acetate buffer, $\mathrm{pH}$ 4.0) was added and mixed with the extract. The sample was then incubated at $37^{\circ} \mathrm{C}$ for $30 \mathrm{~min}$, after which $500 \mu \mathrm{l}$ DNS (3,5-dinitro salicylic acid; Solarbio, Beijing, China) was added to detect the galacturonic acid generated. The reaction mixture was then boiled for $5 \mathrm{~min}$, quickly cooled, and $1.25 \mathrm{ml}$ distilled water was added to the reaction system before measuring the absorbance of the reaction mixture at $540 \mathrm{~nm}$ to determine the concentration of the galacturonic acid produced. $\mathrm{D}-(+)$-galacturonic acid was used as the standard sample to construct the standard curve.

\section{Cel activity assay}

The preparation and enzyme extraction of the petiole AZ tissues was similar to that described above for PG activity detection, except that the extraction buffer was $100 \mathrm{mM}$ acetate buffer, $\mathrm{pH} 4.6$, and the substrate in this assay was sodium carboxymethyl cellulose $(1 \% \mathrm{w} / \mathrm{v}$ in $100 \mathrm{mM}$ acetate buffer, $\mathrm{pH}$ 4.6). The incubation temperature for the reaction in this assay was $40^{\circ} \mathrm{C}$. DNS was again used in this analysis to detect the reducing sugar generated, and glucose standards were used to construct the standard curve.

\section{Prokaryotic expression, protein purification, and enzymatic activity assay}

To express TAPG4 and Cel5 in Escherichia coli, the mature coding region sequences of these two genes were first cloned into the expression vector pCold and then transformed into E. coli BL21 to achieve exogenous protein expression. The expressed recombinant proteins were then purified using a Ni-NTA Sefinose Resin (Sangon Biotech, Shanghai, China), following the manufacturer's instructions, and the purity was confirmed by $10 \%$ sodium dodecyl sulfate-polyacrylamide gel electrophoresis. The purified proteins were then used to detect the activities of PG (TAPG4) and Cel (Cel5), respectively. The protein preparation isolated from the empty pCold vector was used as the negative control. For $\mathrm{H}_{2} \mathrm{~S}$ treatment, its donor $\mathrm{NaHS}$ was combined with the protein solutions directly at different concentrations $(0,10,20,30,40 \mu \mathrm{M})$ as reported previously $^{30}$.

\section{Abscission or dehiscence analysis in other plant species exposed to $\mathrm{H}_{2} \mathrm{~S}$}

Flowering stems of rose (cv. Yingxing) and lily (cv. Suoerbang) were obtained from the local flower market in Taiyuan, China. Each flower material was divided into two groups that were exposed to either ethylene or the ethylene- $\mathrm{H}_{2} \mathrm{~S}$ combination using the same concentrations and the treatment method as described earlier. For the floral organ abscission analysis of roses, the abscission rate was recorded every $3 \mathrm{~h}$ and photographed every $6 \mathrm{~h}$ after treatment. For the anther dehiscence assay of lilies, all treatments were performed for $22 \mathrm{~h}$ in airtight containers, and then the treatments were removed and the anthers were exposed to the air. At this time point, the anther in the ethylene-treated group immediately began to open after the container was removed. Then the dehiscence rates of these anthers were recorded every $20 \mathrm{~min}$ after being exposed to the air.

\section{Statistical analysis}

For each sample and assay, three biological and three technical replicates were performed, and the summary statistics of the data are presented as the mean \pm standard error (SE). Duncan's multiple range test of the SPSS 19.0 software (IBM, Armonk, NY, USA) was used for all data analyses, with $P<0.05$ as the threshold level for significance. 


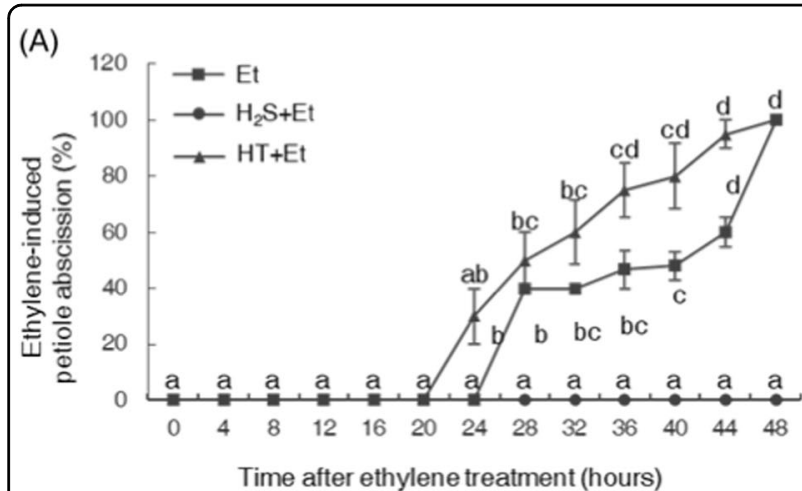

(B)

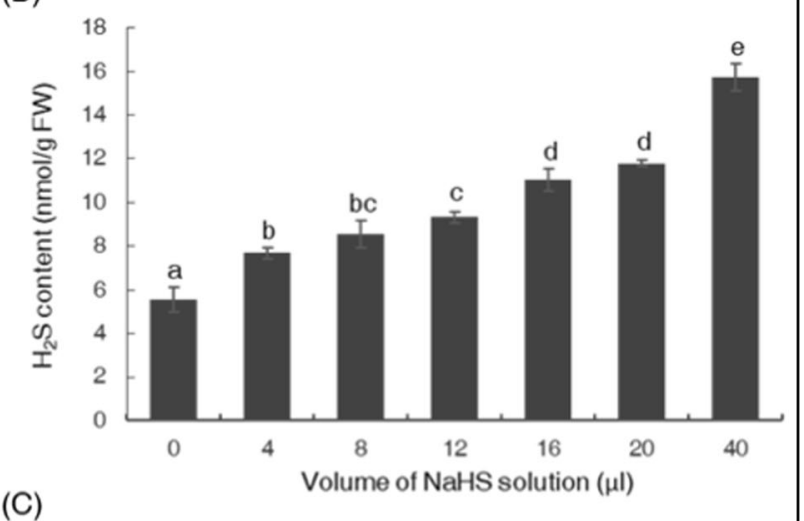

(C)

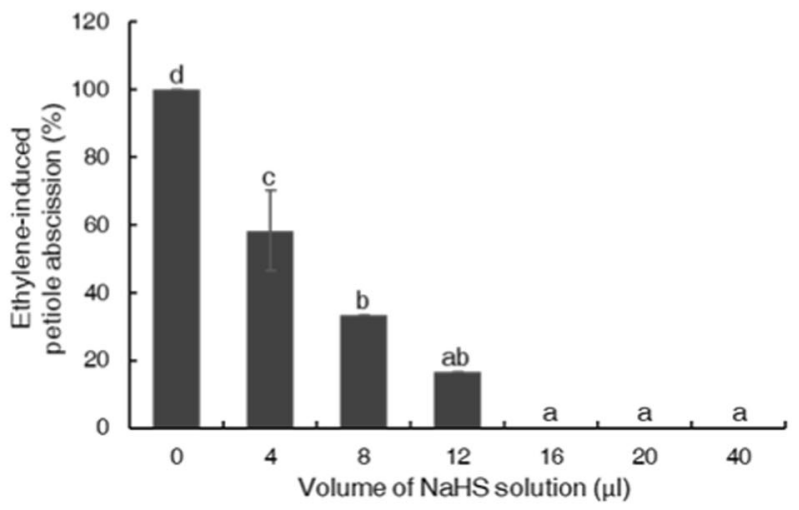

Fig. $1 \mathrm{H}_{2} \mathrm{~S}$ inhibited the process of petiole abscission in tomato. a Hydrogen sulfide $\left(\mathrm{H}_{2} \mathrm{~S}\right)$ and its scavenger hypotaurine $(\mathrm{HT})$ acted antagonistically during petiole abscission. $\mathrm{H}_{2} \mathrm{~S}$ was supplied by sodium hydrosulfide $\left(16 \mu \mathrm{l}\right.$ of $1 \mathrm{M} \mathrm{NaHS}$ solution), with $\mathrm{HT}(1 \mathrm{mM})$ as the $\mathrm{H}_{2} \mathrm{~S}$ scavenger. $\mathbf{b}$ The endogenous $\mathrm{H}_{2} \mathrm{~S}$ content of the tomato petiole abscission zone tissues fumigated with different concentrations of $\mathrm{H}_{2} \mathrm{~S}$ provided by different amounts of $1 \mathrm{M} \mathrm{NaHS}$ solutions. The $\mathrm{H}_{2} \mathrm{~S}$ contents were measured after incubation with $\mathrm{H}_{2} \mathrm{~S}$ gas for $24 \mathrm{~h}$. c The inhibitory effects of $\mathrm{H}_{2} \mathrm{~S}$ on petiole abscission are concentration dependent. The petiole abscission rates were recorded after treatment for $48 \mathrm{~h}$

\section{Results}

\section{$\mathrm{H}_{2} \mathrm{~S}$ inhibited petiole abscission}

To investigate the effect of $\mathrm{H}_{2} \mathrm{~S}$ on the abscission process of tomato petioles, $\mathrm{H}_{2} \mathrm{~S}$, supplied by NaHS, was applied to the tomato petiole explants at its physiologically active concentration ${ }^{14}$, and any petiole abscission was recorded every $4 \mathrm{~h}$. To synchronize the abscission process of different tomato petiole explants, exogenous ethylene (supplied by ethephon solution) was also applied, as in the natural petiole abscission system; however, the deviation was too large, and the results were hard to replicate (Fig. S1). The results showed that, in the ethylene treatment group, the tomato petioles started to abscise at $28 \mathrm{~h}$ after the initiation of the experiment, nearly half of the petioles had abscised by $36 \mathrm{~h}$ of treatment, and all the tomato petioles abscised by $48 \mathrm{~h}$ of treatment (Fig. 1a). However, in the presence of $\mathrm{H}_{2} \mathrm{~S}$, the petiole abscission was greatly inhibited; at $48 \mathrm{~h}$ after the experiment was set up, petioles in this group $\left(\mathrm{H}_{2} \mathrm{~S}\right.$-ethylene group) did not show any sign of abscission (Fig. 1a). To assess the function of endogenous $\mathrm{H}_{2} \mathrm{~S}$, the $\mathrm{H}_{2} \mathrm{~S}$ scavenger $\mathrm{HT}$ was applied to the tomato petiole together with ethylene. As a result, $\mathrm{H}_{2} \mathrm{~S}$ scavenging accelerated abscission, as abscission in this group started at $24 \mathrm{~h}$, and $>60 \%$ of the petioles had abscised by $36 \mathrm{~h}$ treatment (Fig. 1a).

To rule out the possibility that $\mathrm{H}_{2} \mathrm{~S}$ might affect petiole abscission by inhibiting the release of ethylene from ethephon, a triple response analysis was conducted under treatments with different combinations of ethylene and $\mathrm{H}_{2} \mathrm{~S}$. The results showed that the hypocotyls of the tomato seedlings treated with ethylene or $\mathrm{H}_{2} \mathrm{~S}$-ethylene exhibited the same degree of shortening compared with the nontreatment group, indicating that $\mathrm{H}_{2} \mathrm{~S}$ did not inhibit the release of ethylene from ethephon (Fig. S2).

To further investigate the relationship between $\mathrm{H}_{2} \mathrm{~S}$ and the inhibition of petiole abscission, we compared the abscission rate under different $\mathrm{H}_{2} \mathrm{~S}$ levels provided by different amounts of NaHS solutions (Fig. 1b). Our data showed that the inhibitory effect of $\mathrm{H}_{2} \mathrm{~S}$ on petiole abscission was concentration dependent. When the amounts of the $\mathrm{H}_{2} \mathrm{~S}$ donor (NaHS) solutions increased from 0 to $16 \mu \mathrm{l}$, the abscission rate decreased from $100 \%$ to $0 \%$, indicating that $\mathrm{H}_{2} \mathrm{~S}$ was a novel regulator of the process of tomato petiole abscission (Fig. 1c).

\section{$\mathrm{H}_{2} \mathrm{~S}$ inhibited both PG and Cel activities in the petiole $\mathrm{AZ}$}

Cell-wall-modifying enzymes play important roles in abscission. To determine the mechanism by which $\mathrm{H}_{2} \mathrm{~S}$ inhibited petiole abscission, we measured both PG and Cel activities in petiole AZ tissues during petiole abscission under $\mathrm{H}_{2} \mathrm{~S}$ treatment. The results showed that, in the ethylene treatment group, the activities of both enzymes increased dramatically as abscission progressed (Fig. 2). However, in the $\mathrm{H}_{2} \mathrm{~S}$-ethylene treatment group, PG activity remained at a significantly lower level during treatment (Fig. 2a), while the activity of Cel increased only slightly over the same time period (Fig. $2 b$ ). 


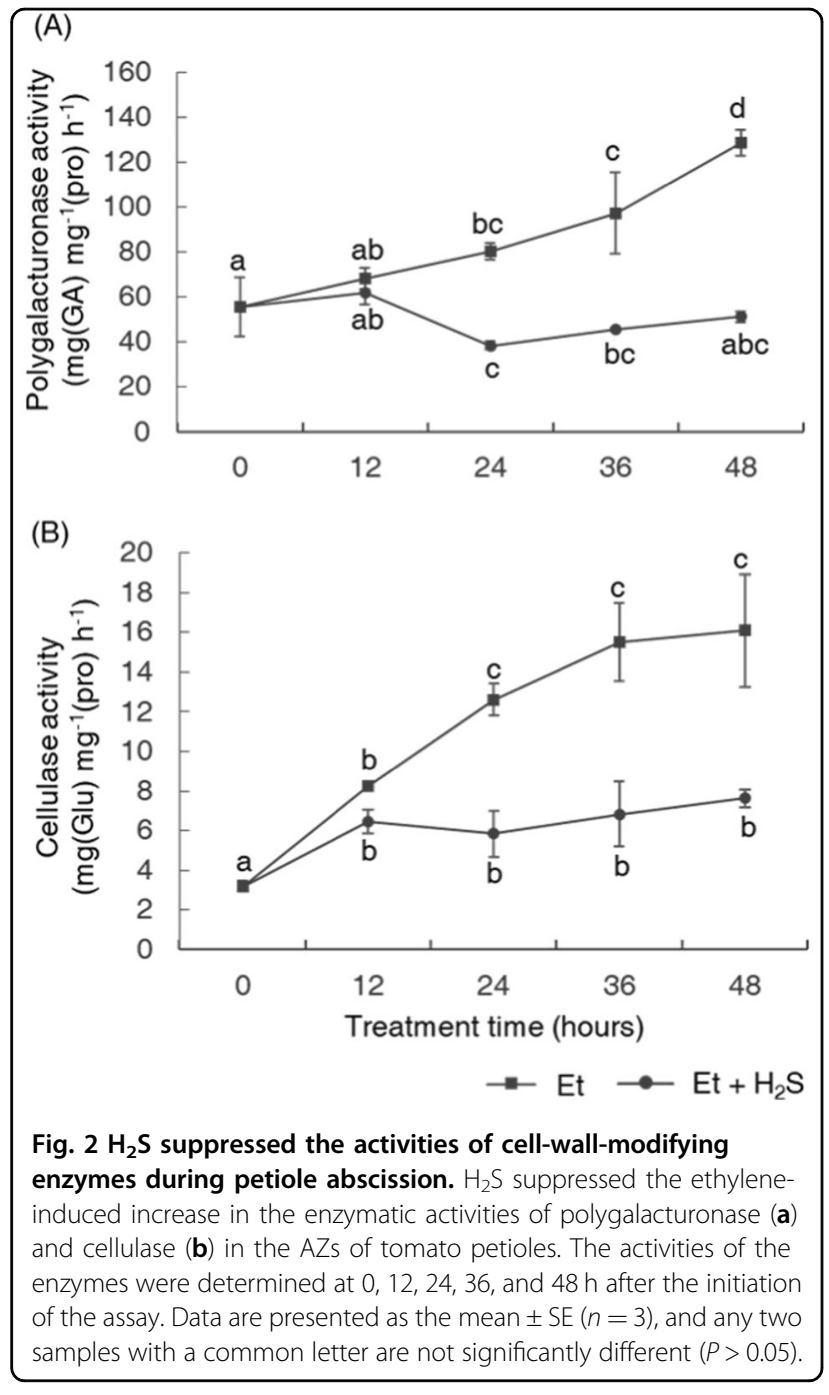

$\mathrm{H}_{2} \mathrm{~S}$ suppressed the upregulation of genes encoding cellwall-modifying enzymes

As $\mathrm{H}_{2} \mathrm{~S}$ inhibited the activities of cell-wall-modifying enzymes in the petiole AZs, we investigated whether this was due to an effect of $\mathrm{H}_{2} \mathrm{~S}$ on the transcription of the genes encoding these enzymes. We monitored the expression levels of the genes Cel5, TAPG2, TAPG4, and Expansin1, which have been reported to be involved in the process of abscission in tomato and encode cell-wallmodifying enzymes ${ }^{16,31,32}$. In the ethylene treatment group, the expression levels of all four genes increased sharply and significantly after $12 \mathrm{~h}$, reaching their expression peaks at 24 or $36 \mathrm{~h}$ (Fig. 3). However, in the $\mathrm{H}_{2} \mathrm{~S}$-ethylene treatment group, the upregulation of all four genes was inhibited, indicating that $\mathrm{H}_{2} \mathrm{~S}$ significantly suppressed the transcription of these genes associated with the biosynthesis of cell-wall-modifying enzymes in petiole abscission (Fig. 3).

\section{Effect of $\mathrm{H}_{2} \mathrm{~S}$ on PG and Cel activities in vitro}

It has been reported that $\mathrm{H}_{2} \mathrm{~S}$ can directly affect the function of a protein through posttranslational modification ${ }^{33}$; therefore, to further evaluate how $\mathrm{H}_{2} \mathrm{~S}$ regulates the activities of cell-wall-modifying enzymes, we next analyzed the effect of $\mathrm{H}_{2} \mathrm{~S}$ on several key enzymes involved in the abscission process, namely, TAPG4 and Cel5, at the protein level. Both the TAPG4 and Cel5 proteins were exogenously expressed and purified (Fig. 4a), and the activity changes in these two proteins after treating explants with different concentrations of $\mathrm{H}_{2} \mathrm{~S}$ (provided by NaHS), within the range of physiologically active concentrations, were monitored. We found that, when the concentration of the $\mathrm{H}_{2} \mathrm{~S}$ donor (NaHS) reached $40 \mu \mathrm{M}$, the activity of Cel5 was only slightly reduced (Fig. 4b), while the activity of TAPG4 did not show any significant changes at the same concentrations of NaHS as those used in the petiole abscission assay (Fig. 4c). No significant correlation could be detected between the activity levels of either enzyme or the NaHS concentration.

\section{$\mathrm{H}_{2} \mathrm{~S}$ affected the endogenous biosynthesis and/or signaling of ethylene and auxin}

Because $\mathrm{H}_{2} \mathrm{~S}$ inhibited petiole abscission in the presence of ethylene, we wondered whether $\mathrm{H}_{2} \mathrm{~S}$ interfered with the action of ethylene during this process. To test this hypothesis, we analyzed a number of key genes, namely, ACS, ACS6, ACO1, ACO4, ERF1, and ETR4, which had previously been shown to be involved in the biosynthesis or signaling of ethylene and to play essential roles during the process of abscission in tomato ${ }^{31}$. Realtime qPCR assays between the ethylene treatment group and the $\mathrm{H}_{2} \mathrm{~S}$-ethylene treatment group showed that $\mathrm{H}_{2} \mathrm{~S}$ suppressed the upregulation of the transcription of the genes ACS6, ACO1, ACO4, ERF1, and ETR4 in the late stages of the abscission process, especially after $24 \mathrm{~h}$. However, the transcription of $A C S$ was significantly increased by $\mathrm{H}_{2} \mathrm{~S}$, resulting in an expression peak at $36 \mathrm{~h}$ of treatment (Fig. 5a).

Auxin is also an essential hormone in the timing of the abscission process, and the level of auxin within the AZ tissues plays a crucial role in maintaining the insensitivity of $\mathrm{AZ}$ cells to ethylene and inhibits the occurrence of abscission. To assess the status of auxin in AZ tissues, the transcription levels of IAA/AUX family genes (SIIAA4 and SIIAA3) and the genes from the IAA-amino acid conjugate hydrolase (ILR) family (ILR-L3 and ILR-L4) were analyzed (Fig. 5b). The expression of these genes was an indicator of the auxin status in vivo. Our results showed that $\mathrm{H}_{2} \mathrm{~S}$ significantly upregulated the expression of the $I A A / A U X$ genes in the earlier stages of the abscission process, especially before $24 \mathrm{~h}$ after treatment. The transcription of the ILR family genes was downregulated in 


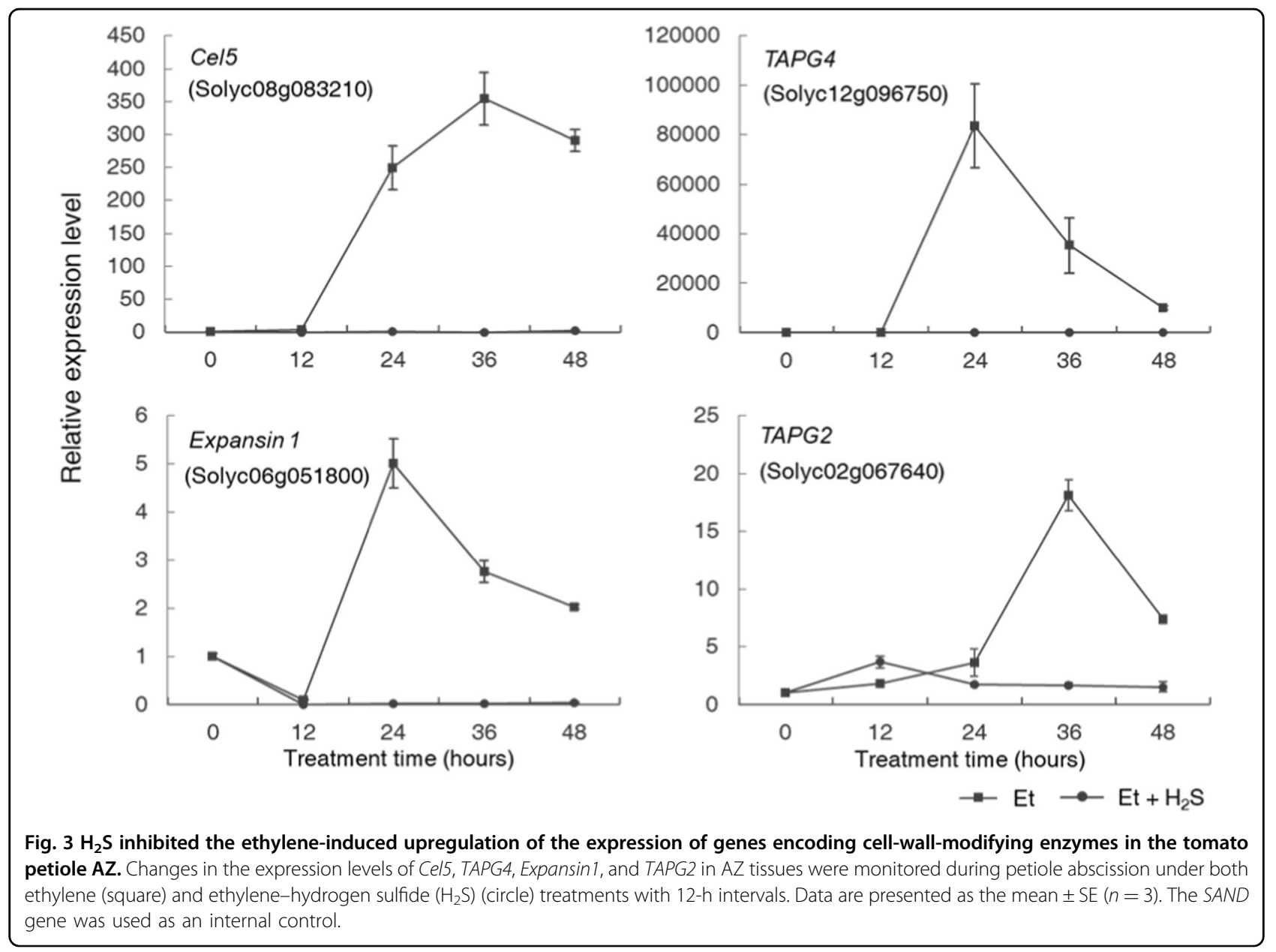

the $\mathrm{H}_{2} \mathrm{~S}$ treatment group compared to the ethylene treatment group in the same time phase (Fig. 5b), suggesting an increase in the content of the bioactive-free auxin in the $\mathrm{H}_{2} \mathrm{~S}$-treated $\mathrm{AZ}$ tissues.

\section{$\mathrm{H}_{2} \mathrm{~S}$ inhibited other cell separation processes in different plant species}

To investigate whether $\mathrm{H}_{2} \mathrm{~S}$ affected other abscission or cell separation processes in plants, we further analyzed the effects of $\mathrm{H}_{2} \mathrm{~S}$ on floral organ abscission in rose and on anther dehiscence in lily. In the floral organ abscission assay, $\mathrm{H}_{2} \mathrm{~S}$ (provided by NaHS solution) was applied, and ethylene (provided by ethephon solution) was also used to synchronize abscission. As shown in Fig. 6, half of the rose floral organs treated with only ethylene were abscised at $6 \mathrm{~h}$ after treatment (Fig. 6a, b), with all the petals abscised by the $12 \mathrm{~h}$ treatment time point. In addition, leaf abscission was also complete at $12 \mathrm{~h}$ of exposure to ethylene (Fig. S3). However, under $\mathrm{H}_{2} \mathrm{~S}$ treatment, rose petal abscission did not start even at $12 \mathrm{~h}$ after the initiation of the $\mathrm{H}_{2} \mathrm{~S}$ treatment (Fig. 6a, b). Moreover, $\mathrm{H}_{2} \mathrm{~S}$ also inhibited the dehiscence of the anthers in lily.
Anthers in the ethylene treatment group began to dehisce by $22 \mathrm{~h}$ of treatment, whereas in the $\mathrm{H}_{2} \mathrm{~S}$-ethylene treatment group, the anthers did not show any sign of dehiscence even at $23 \mathrm{~h}$ after the initiation of the treatment, by which time the anthers in the ethylene treatment group were already fully dehiscent (Fig. 6c, d).

\section{Discussion}

Hydrogen sulfide functioned as a novel regulator during the process of plant organ abscission

Abscission is a ubiquitous and dynamic process in the life cycle of plants. It helps plants defend themselves against adverse conditions by detaching damaged or infected organs, and it can also help plants disseminate their offspring through seed dispersal. In general, the very shape of plants is controlled by the processes of both growth and abscission ${ }^{1}$. In the past few decades, multiple phytohormones have been shown to be involved in the process of abscission, including ethylene ${ }^{7-9}$, auxin ${ }^{11}$, jasmonic $\operatorname{acid}^{34}$, and salicylic acid ${ }^{35}$. In modern agriculture production, many analogs or antagonisms of these hormones have also been applied in orchards to improve 


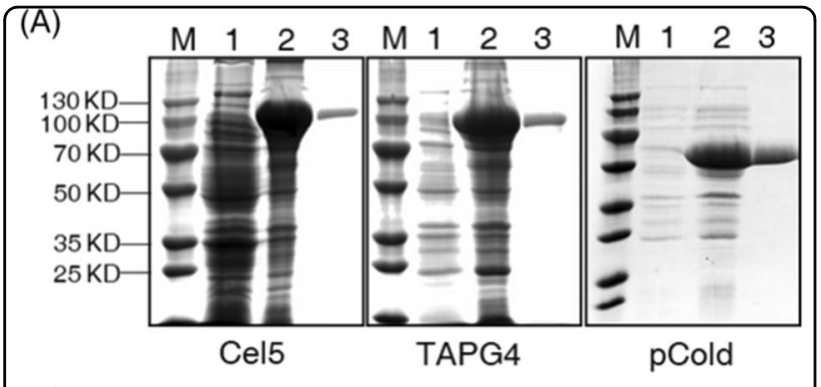

(B)

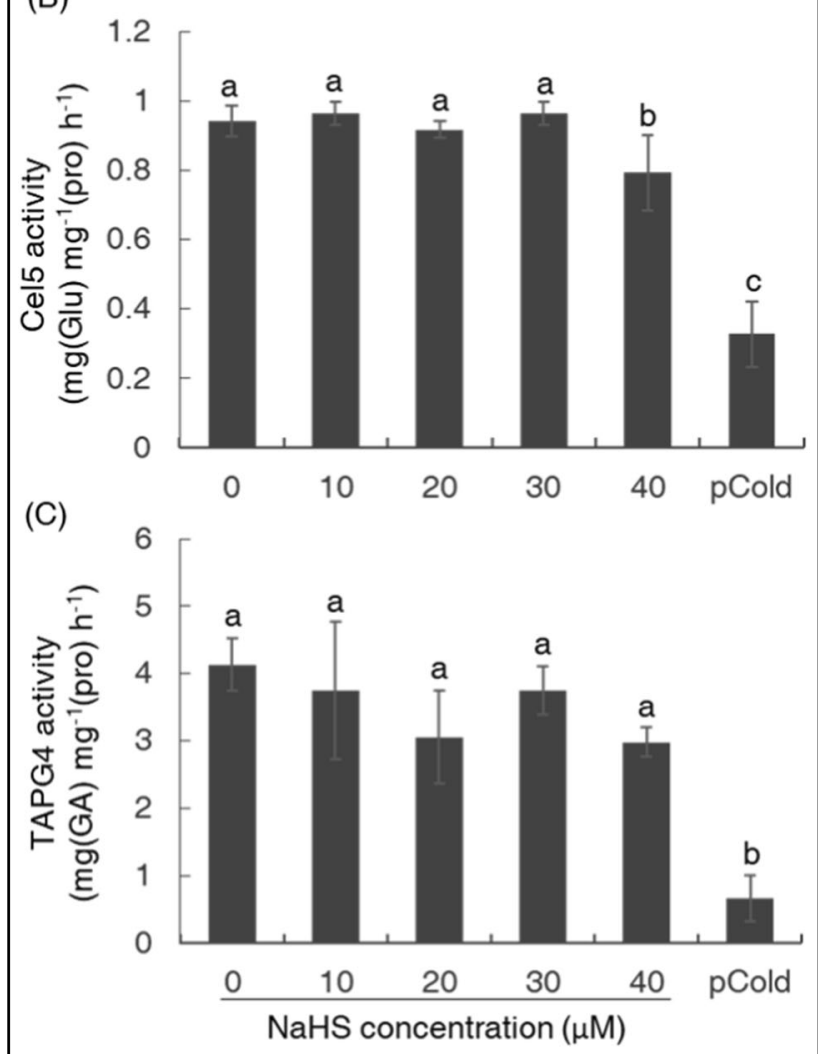

Fig. $4 \mathrm{H}_{2} \mathrm{~S}$ did not inhibit the activities of cell-wall-modifying proteins directly. Detection of the purified exogenously expressed Cel5 and TAPG4 proteins (a) and the effects of NaHS concentrations on their activities in vitro $(\mathbf{b}, \mathbf{c})$. M, protein molecular weight ladder; 1 , proteins extracted from uninduced Escherichia coli; 2, proteins extracted from isopropyl $\beta$-D-thiogalactoside (IPTG)-induced E. coli; 3, the purified protein. Protein produced by the empty pCold vector was used as a negative control. Data are presented as the mean \pm SE $(n=$ $3)$, and different letters indicate significant differences $(P<0.05)$.

agricultural output or facilitate agricultural production activities $^{1}$.

In the current study, we found that $\mathrm{H}_{2} \mathrm{~S}$, a newly discovered gasotransmitter ${ }^{18}$, also had a regulatory function during the abscission process at its physiologically active concentration (Fig. 1a). The exogenous application of $\mathrm{H}_{2} \mathrm{~S}$ not only inhibited petiole abscission in tomato but also affected floral organ abscission in rose and anther dehiscence in lily (Fig. 6), indicating that the regulatory function of $\mathrm{H}_{2} \mathrm{~S}$ with respect to the abscission process is widespread in the plant kingdom. In this work, we also found that the application of a $\mathrm{H}_{2} \mathrm{~S}$ scavenger $(\mathrm{HT})$ accelerated the process of abscission (Fig. 1a), indicating that, during the natural abscission process, endogenous $\mathrm{H}_{2} \mathrm{~S}$ might also occupy an important position in the regulatory network.

Currently, several chemicals, which are inexpensive and easy to obtain ${ }^{36}$, have been shown to act as sources of $\mathrm{H}_{2} \mathrm{~S}$. As $\mathrm{H}_{2} \mathrm{~S}$ at its physiological concentration also benefits human health ${ }^{18}$, it would be interesting to develop $\mathrm{H}_{2} \mathrm{~S}$ as a new abscission regulator by manipulating exposure to $\mathrm{H}_{2} \mathrm{~S}$ donor chemicals.

\section{$\mathrm{H}_{2} \mathrm{~S}$ inhibited the activity of cell-wall-modifying enzymes by downregulating gene transcription}

The increased activity of cell-wall-modifying enzymes, such as Cels and PGs, is an important indicator of the activation of abscission ${ }^{37}$. These enzymes work together to breakdown the adhesion between AZ cells and to promote cell separation. In the current study, we found that, compared with ethylene treatment alone, $\mathrm{H}_{2} \mathrm{~S}$ treatment markedly suppressed the normal increase in the activities of both Cels and PGs (Fig. 2), and our research also revealed that $\mathrm{H}_{2} \mathrm{~S}$ significantly inhibited the upregulation of genes encoding these enzymes during abscission (Fig. 3) but had little to no effects on these enzymes directly at the protein level via posttranslational modification (Fig. 4). These findings demonstrated that $\mathrm{H}_{2} \mathrm{~S}$ probably functioned in achieving competence to respond to abscission signals or played a role in the transduction of abscission signals, as the transcriptional upregulation of genes encoding cell-wall-modifying enzymes indicates that the abscission signals had been passed far downstream and that the abscission process had been initiated $^{37-39}$.

\section{$\mathrm{H}_{2} \mathrm{~S}$ might maintain the insensitivity of $\mathrm{AZ}$ tissues to ethylene by modulating the content of bioactive-free auxin locally}

As mentioned above, ethylene and auxin are important hormones regulating the process of abscission ${ }^{9,11}$. These two hormones have been suggested to work together in the timing of abscission ${ }^{7}$. To explore the mechanism underlying the inhibitory function of $\mathrm{H}_{2} \mathrm{~S}$ during the process of petiole abscission in tomato, the expression changes in ethylene- and auxin-related genes were analyzed in this study. Our results showed that $\mathrm{H}_{2} \mathrm{~S}$ interfered with ethylene signaling during abscission, as five out of the six genes examined (related to ethylene biosynthesis or signaling), which have been reported to be involved in the process of abscission, exhibited decreased transcription in response to $\mathrm{H}_{2} \mathrm{~S}$ treatment compared to ethylene 

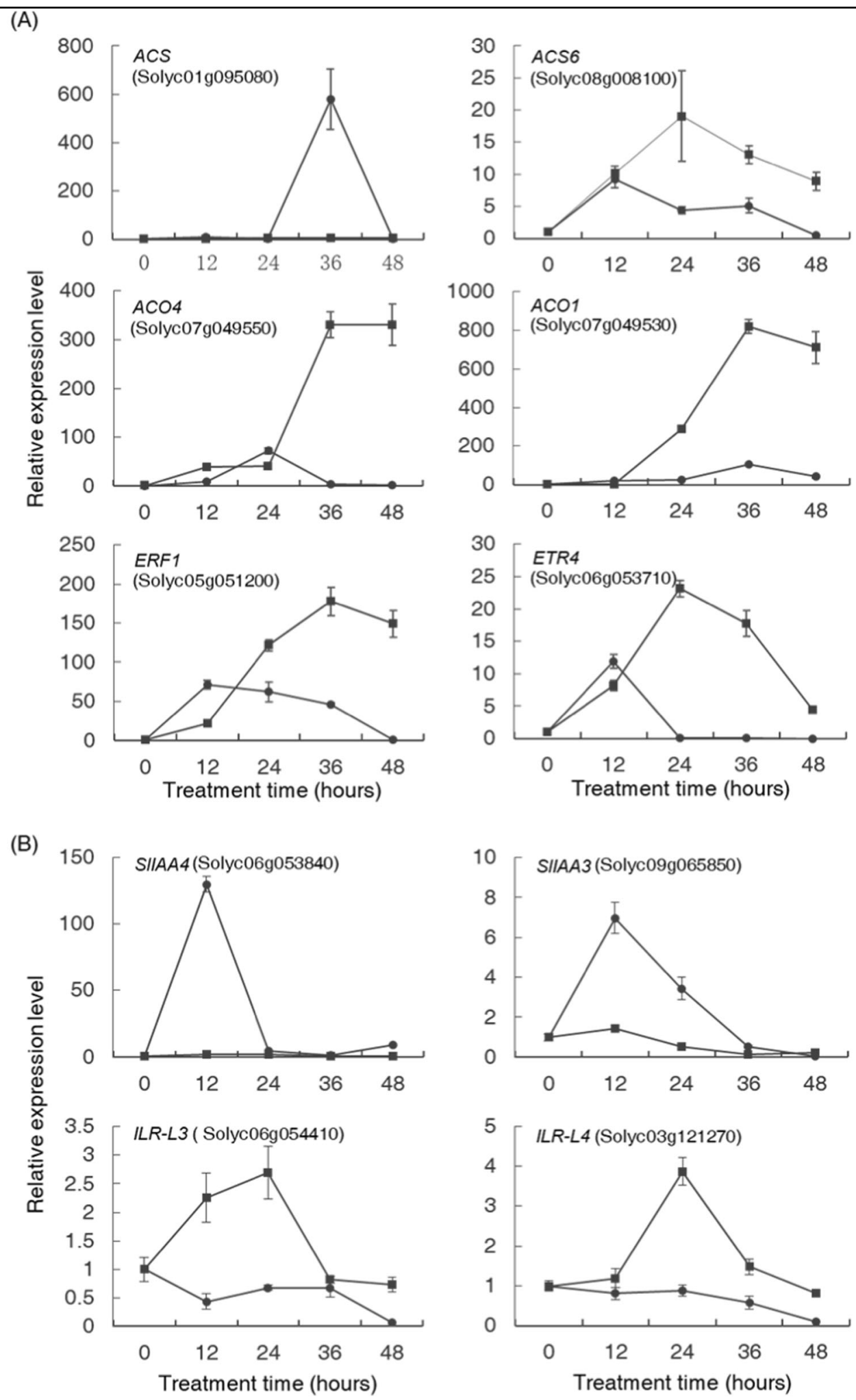

$$
\rightarrow-E t \rightarrow E t+\mathrm{H}_{2} \mathrm{~S}
$$

Fig. $5 \mathrm{H}_{2} \mathrm{~S}$ affected the transcription of genes involved in the signaling of ethylene and auxin. Effect of $\mathrm{H}_{2} \mathrm{~S}$ on changes in the transcription levels of $\mathbf{a}$ ethylene biosynthesis (ACS, ACS6, ACO4, and ACO1) or ethylene signaling-related (ERF1 and ETR4) genes and $\mathbf{b}$ indicator genes of the bioactive-free auxin in the petiole abscission zone (AZ) during ethylene-induced abscission. mRNAs were extracted from AZ tissues under ethylene (squares) or ethylene- $\mathrm{H}_{2} \mathrm{~S}$ (circles) treatments at the time points of $0,12,24,36$, and $48 \mathrm{~h}$. Data are presented as the mean \pm SE $(n=3)$. The SAND gene was used as an internal control. 


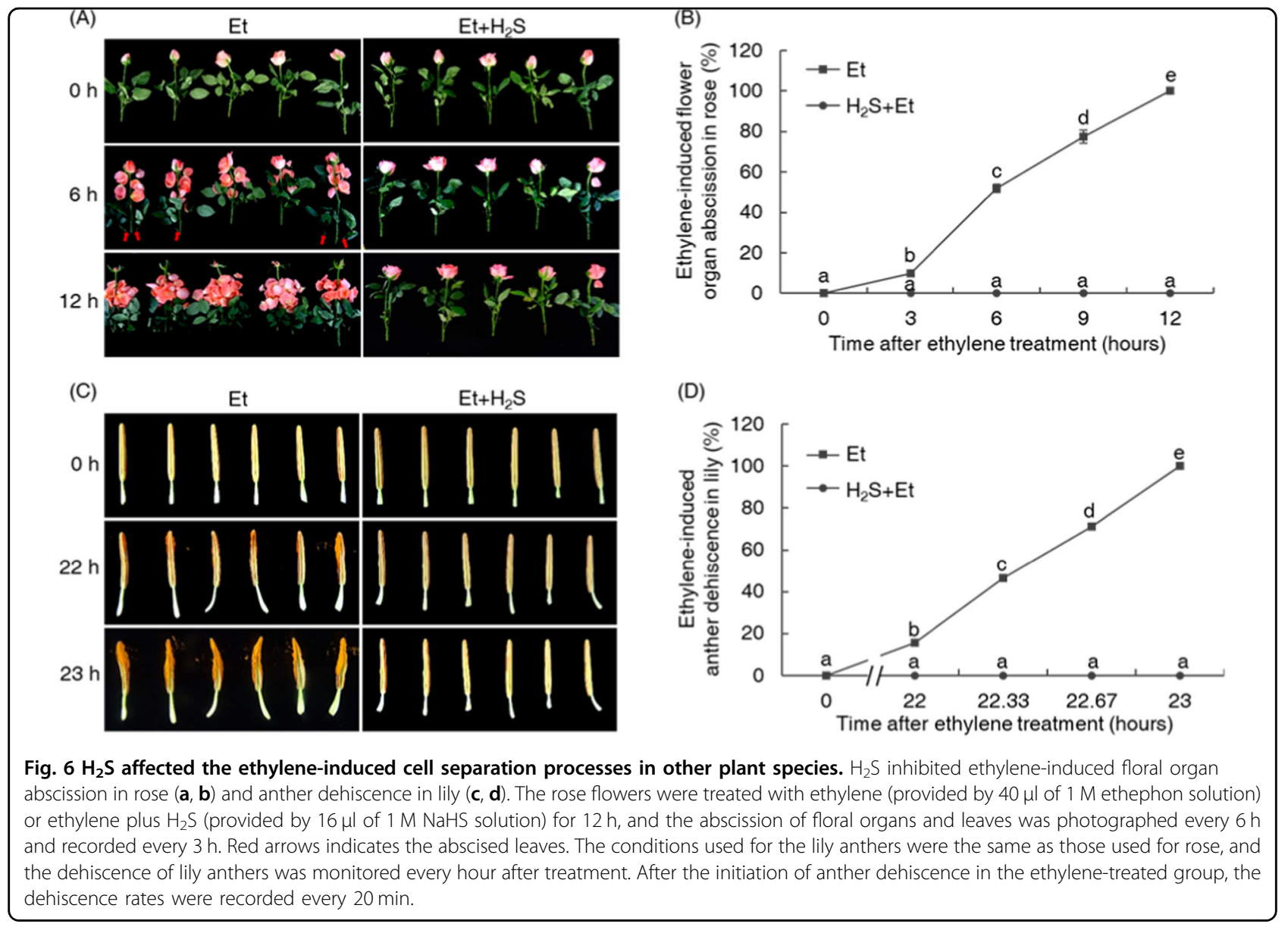

treatment ${ }^{31,32}$. Among the five regulated genes, three genes (ACS6, ACO4, and ACO1) were related to ethylene biosynthesis. Their expression peaked after $24 \mathrm{~h}$, indicating that these genes were also involved in the phenomenon of ethylene autocatalysis, which occurred 24-48 h after ethylene treatment ${ }^{40-42}$. The regulatory effects of $\mathrm{H}_{2} \mathrm{~S}$ on these genes also indicated that, in the petiole abscission process under ethylene treatment, $\mathrm{H}_{2} \mathrm{~S}$ also affected the autocatalytic effect of ethylene. The transcriptional-level analyses of the other two ethylene signaling-related genes (ERF1 and ETR4) showed that, under ethylene treatment, the expression of these two genes was upregulated significantly from earlier stages of abscission, and thus they might be involved in the signaling network that leads to the initiation of the abscission process. However, under $\mathrm{H}_{2} \mathrm{~S}-$ ethylene treatment, the transcription of these two genes only began to decrease after $12 \mathrm{~h}$, and after $24 \mathrm{~h}$ of treatment, the expression decline became significant in the $\mathrm{H}_{2} \mathrm{~S}$-ethylene treatment group compared to the ethylene treatment group (Fig. 5a). In the transcriptional analysis of the cell-wall-modifying-related genes under $\mathrm{H}_{2} \mathrm{~S}$ treatment, we found that $\mathrm{H}_{2} \mathrm{~S}$ inhibited the transcription of these genes from earlier stages of the abscission process
(Fig. 3), indicating that the interference of $\mathrm{H}_{2} \mathrm{~S}$ with ethylene signaling might not be the major function of $\mathrm{H}_{2} \mathrm{~S}$ in abscission initiation. Regarding the inhibitory effect of $\mathrm{H}_{2} \mathrm{~S}$ on these ethylene-related genes in later stages of abscission, future studies are needed to clarify whether $\mathrm{H}_{2} \mathrm{~S}$ also has a role in the subsequent abscission processes.

The regulatory effects of $\mathrm{H}_{2} \mathrm{~S}$ on auxin occurred in the earlier stages of abscission process. IAA/AUX proteins are repressors of the transduction of the auxin signal, but the transcription of some members of this family was always rapidly induced by the elevated free auxin level to ensure a strictly controlled transient response to changes in the auxin concentration through negative feedback ${ }^{31,43}$. Here two IAA/AUX family genes, which have been shown to respond to the changes in the auxin content rapidly ${ }^{31}$, were promoted dramatically in earlier stages of the abscission process after $\mathrm{H}_{2} \mathrm{~S}$ treatment (Fig. 5b), suggesting an increase in the bioactive-free auxin in these $\mathrm{H}_{2} \mathrm{~S}$-treated AZ tissues. This deduction was further confirmed by the changing expression patterns of two ILR family genes. Enzymes encoded by this kind of genes promote the hydrolysis of IAA conjugates to release bioactive-free auxin ${ }^{44}$. The transcription of some genes from this family can be upregulated when the surrounding 
free auxin is deficient and the IAA conjugates are needed to be activated ${ }^{31}$. In this study, we found that the expression of two ILR genes was inhibited under $\mathrm{H}_{2} \mathrm{~S}$-ethylene treatment compared with ethylene treatment (Fig. 5b), indicating that the content of the free bioactive auxin in the $\mathrm{H}_{2} \mathrm{~S}$-treated $\mathrm{AZ}$ tissues was relatively high. As auxin has an important role in step 2 of abscission ${ }^{7}$, it is likely that $\mathrm{H}_{2} \mathrm{~S}$ functioned in the second step of the abscission process by preventing the AZ cells from obtaining the competence to respond to abscission signals by modulating the content of the biologically active free auxin in these cells. Regarding the regulatory effect of $\mathrm{H}_{2} \mathrm{~S}$ on ethylene-related genes in the abscission process after ethylene treatment, it is possible that $\mathrm{H}_{2} \mathrm{~S}$ functioned by enhancing the content of bioactive auxin in AZ tissues, as it has been shown that IAA can inhibit the ethylene-regulated expression of ACO and ACS genes ${ }^{45}$. On the other hand, $\mathrm{H}_{2} \mathrm{~S}$ might also have other ways to regulate the transcription of these genes because the expression of the ACS gene was enhanced by $\mathrm{H}_{2} \mathrm{~S}$ in this analysis, and the inhibitory effect of auxin on this gene has previously been detected ${ }^{27}$. Thus our expression analysis results actually presented an integrated regulatory effect of $\mathrm{H}_{2} \mathrm{~S}$, and the exact regulatory mechanism underlying these phenomena still needs further elucidation.

\section{$\mathrm{H}_{2} \mathrm{~S}$ functioned differentially in two ethylene-related physiological processes}

The triple response is the typical phenotype after ethylene treatment, which consists of the exaggeration of the apical hook curvature and the thickening and shortening of hypocotyls and roots ${ }^{46}$. In this study, we found that, although $\mathrm{H}_{2} \mathrm{~S}$ inhibited ethylene-induced petiole abscission in tomato (Fig. 1), this gasotransmitter showed no obvious effect on the triple response caused by the exogenous ethylene treatment (Fig. S2).

Regarding the functional discrepancy of $\mathrm{H}_{2} \mathrm{~S}$ during these two processes, one possible explanation is that the regulatory mechanisms underlying these two processes are not identical, or in other words, they are mostly different. In the abscission process, it is well known that ethylene and auxin act antagonistically to regulate the timing of abscission ${ }^{1}$. In the triple response, evidence has shown that a partially synergistic relationship exists between these two hormones ${ }^{46}$, suggesting the complexity of the interaction of these two hormones in different physiological processes. On the other hand, it has recently been shown that the S-sulfhydration of the target proteins is an important mode of action for $\mathrm{H}_{2} \mathrm{~S}^{30}$. As the components of both ethylene and auxin signaling pathways have expression preferences in different physiological processes ${ }^{47}$, it is possible that in the abscission process the upstream factors of the auxin signaling-and/or ethylene signaling-related genes could be modified and affected by $\mathrm{H}_{2} \mathrm{~S}$ and thus affect the transcription of the downstream genes. However, in the triple response, no such factors exist, and no obvious effect could be detected after $\mathrm{H}_{2} \mathrm{~S}$ treatment.

In addition to auxin and ethylene, $\mathrm{H}_{2} \mathrm{~S}$ also interacts widely with other phytohormones, such as gibberellins, salicylic acid, and abscisic acid, in diverse processes during the development and stress responses of plants. It seems that $\mathrm{H}_{2} \mathrm{~S}$ functions as a "referee" to harmonize the interaction between hormones and, as such, should be considered to be an integral molecule in the hormone signaling network of plants ${ }^{48}$. The determination of the detailed mechanism of the interactions between $\mathrm{H}_{2} \mathrm{~S}$ and these phytohormones during the respective physiological processes will be valuable.

\section{Acknowledgements}

This work was funded by the National Natural Science Foundation of China (31501772) and the Scientific and Technological Innovation Programs of Higher Education Institutions in Shanxi (201802015). We thank International Science Editing (http://www.internationalscienceediting.com) for editing this manuscript.

\section{Author contributions}

D.L., Y.P., and J.L. designed the experiments and wrote the manuscript. J.L., D.L., and Z.L. performed the experiments. D.L. and J.L. analyzed the data. All authors read and approved the final manuscript.

\section{Conflict of interest}

The authors declare that they have no conflict of interest.

Supplementary Information accompanies this paper at (https://doi.org/ 10.1038/s41438-019-0237-0).

Received: 9 July 2019 Revised: 27 November 2019 Accepted: 5 December 2019

Published online: 01 February 2020

\section{References}

1. Patharkar, O. R. \& Walker, J. C. Advances in abscission signaling. J. Exp. Bot. 69, 733-740 (2018).

2. Olsson, V. \& Butenko, M. A. Abscission in plants. Curr. Biol. 28, R338-R339 (2018).

3. Zhao, W., Baldwin, E. A., Bai, J., Plotto, A. \& Irey, M. Comparative analysis of the transcriptomes of the calyx abscission zone of sweet orange insights into the huanglongbing-associated fruit abscission. Hortic. Res. 6, 71 (2019).

4. Patterson, S. E. Cutting loose. Abscission and dehiscence in Arabidopsis. Plant Physiol. 126, 494-500 (2001).

5. Taylor, J. E. \& Whitelaw, C. A. Signals in abscission. N. Phytol. 151, 323-339 (2001).

6. Sundaresan, S. et al. The Tomato Hybrid Proline-rich Protein regulates the abscission zone competence to respond to ethylene signals. Hortic. Res. 5, 28 (2018).

7. Meir, S. et al. Re-evaluation of the ethylene-dependent and -independent pathways in the regulation of floral and organ abscission. J. Exp. Bot. 70, 1461-1467 (2019).

8. Patterson, S. E. \& Bleecker, A. B. Ethylene-dependent and -independent processes associated with floral organ abscission in Arabidopsis. Plant Physiol. 134, 194-203 (2004)

9. Botton, A. \& Ruperti, B. The yes and no of the ethylene involvement in abscission. Plants https://doi.org/10.3390/plants8060187 (2019). 
10. Sexton, R. \& Roberts, J. A. Cell biology of abscission. Annu. Rev. Plant Physiol. 33, 133-162 (1982).

11. Basu, M. M. et al. The manipulation of auxin in the abscission zone cells of Arabidopsis flowers reveals that indoleacetic acid signaling is a prerequisite for organ shedding. Plant Physiol. 162, 96-106 (2013).

12. Merelo, P. et al. Cell wall remodeling in abscission zone cells during ethylenepromoted fruit abscission in citrus. Front. Plant Sci. 8, 126 (2017).

13. Daher, F. B. \& Braybrook, S. A. How to let go: pectin and plant cell adhesion. Front. Plant Sci. 6, 523 (2015).

14. Jiang, C. Z., Lu, F., Imsabai, W., Meir, S. \& Reid, M. S. Silencing polygalacturonase expression inhibits tomato petiole abscission. J. Exp. Bot. 59, 973-979 (2008).

15. Taylor, J. E. et al. Polygalacturonase expression during leaf abscission of normal and transgenic tomato plants. Planta 183, 133-138 (1991).

16. Wang, $X$. et al. Transcriptome analysis of tomato flower pedicel tissues reveals abscission zone-specific modulation of key meristem activity genes. PLOS ONE 8, e55238 (2013).

17. Brummell, D. A., Hall, B. D. \& Bennett, A. B. Antisense suppression of tomato endo-1,4-beta-glucanase Cel2 mRNA accumulation increases the force required to break fruit abscission zones but does not affect fruit softening. Plant Mol. Biol. 40, 615-622 (1999).

18. Wang, R. Physiological implications of hydrogen sulfide: a whiff exploration that blossomed. Physiol. Rev. 92, 791-896 (2012).

19. Li, Z. G., Min, X. \& Zhou, Z. H. Hydrogen sulfide: a signal molecule in plant cross-adaptation. Front. Plant Sci. 7, 1621 (2016).

20. Hine, C. et al. Endogenous hydrogen sulfide production is essential for dietary restriction benefits. Cell 160, 132-144 (2015).

21. Fang, T., Cao, Z., Li, J., Shen, W. \& Huang, L. Auxin-induced hydrogen sulfide generation is involved in lateral root formation in tomato. Plant Physiol. Biochem. 76, 44-51 (2014).

22. Mei, Y. et al. L-Cysteine desulfhydrase-dependent hydrogen sulfide is required for methane-induced lateral root formation. Plant Mol. Biol. 99, 283-298 (2019)

23. Yao, G. F. et al. Modulation of enhanced antioxidant activity by hydrogen sulfide antagonization of ethylene in tomato fruit ripening. J. Agric. Food Chem. 66, 10380-10387 (2018).

24. da-Silva, C. J., Mollica, D. C. F., Vicente, M. H., Peres, L. E. P. \& Modolo, L. V. NO, hydrogen sulfide does not come first during tomato response to high salinity. Nitric Oxide 76, 164-173 (2018).

25. Guo, Z. et al. Physiological response and transcription profiling analysis reveals the role of $\mathrm{H} 2 \mathrm{~S}$ in alleviating excess nitrate stress tolerance in tomato roots. Plant Physiol. Biochem. 124, 59-69 (2018).

26. Nakano, T., Fujisawa, M., Shima, Y. \& Ito, Y. The AP2/ERF transcription factor SIERF52 functions in flower pedicel abscission in tomato. J. Exp. Bot. 65 , 3111-3119 (2014).

27. Lai, D. et al. Endogenous hydrogen sulfide enhances salt tolerance by coupling the reestablishment of redox homeostasis and preventing salt-induced $\mathrm{K}+$ loss in seedlings of Medicago sativa. Plant Sci. 225, 117-129 (2014).

28. Exposito-Rodriguez, M., Borges, A. A., Borges-Perez, A.\& Perez, J. A. Selection of internal control genes for quantitative real-time RT-PCR studies during tomato development process. BMC Plant Biol. 8, 131 (2008).

29. Livak, K. J. \& Schmittgen, T. D. Analysis of relative gene expression data using real-time quantitative PCR and the 2(-Delta Delta C(T)) method. Methods $\mathbf{2 5}$ 402-408 (2001).
30. Aroca, Á., Serna, A., Gotor, C. \& Romero, L. C. S-sulfhydration: a cysteine posttranslational modification in plant systems. Plant Physiol. 168, 334-342 (2015).

31. Meir, S. et al. Microarray analysis of the abscission-related transcriptome in the tomato flower abscission zone in response to auxin depletion. Plant Physiol. 154, 1929-1956 (2010).

32. Sundaresan, S. et al. De novo transcriptome sequencing and development of abscission zone-specific microarray as a new molecular tool for analysis of tomato organ abscission. Front. Plant Sci. 6, 1258 (2015).

33. Aroca, A., Benito, J. M., Gotor, C. \& Romero, L. C. Persulfidation proteome reveals the regulation of protein function by hydrogen sulfide in diverse biological processes in Arabidopsis. J. Exp. Bot. 68, 4915-4927 (2017).

34. Kim, J. et al. New clothes for the jasmonic acid receptor COl1: delayed abscission, meristem arrest and apical dominance. PLOS ONE 8, e60505 (2013).

35. Cai, S. \& Lashbrook, C. C. Stamen abscission zone transcriptome profiling reveals new candidates for abscission control: enhanced retention of floral organs in transgenic plants overexpressing Arabidopsis ZINC FINGER PROTEIN2. Plant Physiol. 146, 1305-1321 (2008).

36. Powell, C. R., Dillon, K. M. \& Matson, J. B. A review of hydrogen sulfide $(\mathrm{H} 2 \mathrm{~S})$ donors: Chemistry and potential therapeutic applications. Biochem. Pharmacol 149, 110-123 (2018).

37. Estornell, L. H., Agusti, J., Merelo, P., Talon, M. \& Tadeo, F. R. Elucidating mechanisms underlying organ abscission. Plant Sci. 199-200, 48-60 (2013).

38. Berger, R. K. \& Reid, P. D. Role of polygalacturonase in bean leaf abscission. Plant Physiol. 63, 1133-1137 (1979).

39. Roongsattham, P. et al. Temporal and spatial expression of polygalacturonase gene family members reveals divergent regulation during fleshy fruit ripening and abscission in the monocot species oil palm. BMC Plant Biol. 12, 150 (2012).

40. Kende, H. Ethylene biosythesis. Annu. Rev. Plant Physiol. Plant Mol. Biol. 44 283-307 (1993).

41. Nakatsuka, A. et al. Differential expression and internal feedback regulation of 1-aminocyclopropane-1-carboxylate synthase, 1-aminocyclopropane-1carboxylate oxidase, and ethylene receptor genes in tomato fruit during development and ripening. Plant Physiol. 118, 1295-1305 (1998).

42. Riov, J. \& Yang, S. F. Effects of exogenous ethylene on ethylene production in citrus leaf tissue. Plant Physiol. 70, 136-141 (1982).

43. Woodward, A. W. \& Bartel, B. Auxin: regulation, action, and interaction. Ann. Bot. 95, 707-735 (2005)

44. LeClere, S., Tellez, R., Rampey, R. A., Matsuda, S. P. \& Bartel, B. Characterization of a family of IAA-amino acid conjugate hydrolases from Arabidopsis. J. Biol. Chem. 277, 20446-20452 (2002).

45. Kim, J. H., Kim, W. T. \& Kang, B. G. IAA and N(6)-benzyladenine inhibit ethyleneregulated expression of ACC oxidase and ACC synthase genes in mungbean hypocotyls. Plant Cell Physiol. 42, 1056-1061 (2001).

46. Merchante, C. \& Stepanova, A. N. The triple response assay and its use to characterize ethylene mutants in Arabidopsis. Methods Mol. Biol. 1573, 163-209 (2017).

47. Klay, I. et al. Ethylene Response Factors (ERF) are differentially regulated by different abiotic stress types in tomato plants. Plant Sci. 274, 137-145 (2018).

48. He, H., Garcia-Mata, C. \& He, L.-F. Interaction between hydrogen sulfide and hormones in plant physiological responses. Plant Growth Regul. 87, 175-186 (2019). 